\title{
Affectations, Conformation and Defiance in Americanah by Chimamanda Ngozi Adichie
}

\author{
Abdullah Nejat TÖNGÜR *
}

\begin{abstract}
Chimamanda Ngozi Adichie's third novel Americanah portrays a young Nigerian woman, Ifemelu, who goes to the USA for university education, stays on in the country for 13 years and returns to Nigeria despite the evident success and popularity of her blog in which she writes her observations about Afro-Americans and African immigrants and students in America, her research fellowship at Princeton University, her relationships, her American citizenship and her financial gains. With alternate perspectives of Ifemelu, the protagonist, and her love, Obinze, who lives in the UK as an illegal immigrant for three years, Adichie explores the issue of being a foreigner in another country grappling with financial, social and psychological problems. The aim of this study is to show that the characters with their affectations and aspirations face a dilemma of conformation to or defiance of the cultural and social norms in another country with a hermeneutic approach. This paper also analyses Ifemelu's growing awareness of race, gender and the stereotypes and biases about beauty and how she negotiated her affectations and fallacies with the conclusion that Ifemelu became an Americanah herself slightly with her manners and outlook although she resisted dominant culture for a long time.
\end{abstract}

Keywords: Chimamanda Ngozi Adichie, Americanah, affectations, conformation, defiance.

\footnotetext{
* Doç. Dr., Maltepe Üniversitesi, Eğitim Fakültesi, İngiliz Dili Eğitimi A.B.D., İstanbul, Türkiye. Elmek: nejattongur@maltepe.edu.tr http://orcid.org/0000-0002-1204-4399.
} 


\section{Chimamanda Ngozi Adichie'nin Americanah Adlı Romanında Özentiler, Uyum ve Karşı Koyma}

\section{$\ddot{O} z$}

Chimamanda Ngozi Adichie'nin üçüncü romanı olan Americanah, Amerika Birleşik Devletlerine üniversite eğitimi için giden, orada 13 yıl kalan, Afro-Amerikalılara ve Amerikada'ki Afrikalı göçmen ve öğrencilere dair gözlemlerini yazdığı bloğunun başarısına, Princeton Üniversitesindeki görevine, ilişsilerine, Amerikan vatandaşlığına ve mali kazanımlarına rağmen Nijerya'ya dönen genç bir Nijeryalı kadın portresi çizer. Adichie, romandaki başkarakter Ifemelu'nun ve üç yıl Birleşik Krallık'ta kaçak göçmen olarak yaşayan sevgilisi Obinze'nin farklı bölümlerdeki bakış açıları ve anlatımları yoluyla başka ülkelerde mali, sosyal ve psikolojik sorunlarla mücadele eden yabancılar konusunu araştırmaktadır. Bu çalışmanın amacı hermenötik bir yaklaşımla özentileri ve özlemleriyle karakterlerin bir başka ülkenin kültürel ve sosyal normlarına uyma ya da reddetme ikilemi ile karşı karşıya geldiklerini göstermektir. Bu çalışma, aynı zamanda, Ifemelu'nun ırkla, cinsiyetle ve güzellikle ilgili basmakalıplara ve önyargılara dair artan farkındalığını analiz etmekte ve Ifemelu özentilerinin ve yanlış düşüncelerinin üstesinden nasıl geldiğine ve egemen kültüre uzun süre karşı çıkmasına rağmen davranışları ve bakış açısı ile kendisinin de az da olsa Amerikalı olduğu sonucuna varmaktadır.

Anahtar Kelimeler: Chimamda Ngozi Adichie, Americanah, özentiler, uyum, karşı koyma. 


\section{Genişletilmiş Özet}

Chimamanda Ngozi Adichie'nin üçüncü romanı olan Americanah'da baş karakter Nijeryalı bir genç kadın olan Ifemelu'dur. Kendi ülkesinde üç yıl üniversiteye devam etmesine ragmen uzun uğraşları sonucu Amerika Birleşik Devletlerine üniversite eğitimi için giden Ifemelu 13 yıl kaldığı Amerika'dan Nijerya'ya döner. Trenton, New Jersey'de bir güzellik salonunda başlayan roman 7 bölüm ve 55 kısımdan oluşur ve çoğunlukla Ifemelu'nun, zaman zaman ise Birleşik Krallıkta kaçak olarak üç yıl yaşayan Ifemelu'nun sevgilisi Obinze'nin perspektifinden geriye dönüşlerle olay örgüsü sergilenir. Romanda en fazla ön plana çıkan özellik Ifemelu'nun duygusal ve zihinsel gelişimidir. Hayatına ilk pozitif etki yapanlar ve kişilik gelişimine olumlu katkılar sunanlar halası Uju ve Obinze'nin annesi Bayan Maduewesi olmakla birlikte özellikle Amerika Birleşik Devletleri'nde karşılaştığı mali, psikolojik, sosyal ve kültürel sorunlar karşısında zaman zaman çok büyük zorluklar yaşar. Ifemelu, okuldaki, iş yerindeki ve özel hayatındaki güçlükleri aşmada ve bulunduğu ülkeye uyum sağlamada başarılı olmak ve özendiği yaşama kavuşmak için romanda yer alan pek çok karakterin aksine kişiliğinden, yaşam tarzından, konuşma biçiminden, saç modelinden, alışkanlıklarından taviz vermek istemediği gibi zaman zaman üstü kapalı şekilde ırkçılığa ve ayrımcıllğa maruz kalsa da pes etmez. Önceleri Amerika'da yaşamanın olmadığı gibi davranmak ve -mış gibi yapmakla mümkün olduğunu ve şartlara uyum sağlamak için pek çok alışkanlığın ve davranışını değiştirmesi gerektiğini düşünen Ifemelu aksi taktirde depresyon, mutsuzluk ve başarısızlıkla karşılaşacağını zannetmektedir. Ancak bir süre sonra bu şekilde davranmanın kendisi için uygun olmadığını farkeden Ifemelu, özelliklerini koruyarak ve Amerika'nın hakim olan kültürünün ve toplumun dayatmalarını ve karşı karşıya geldiği kişilerin önyargılarını kabullenmeyip karşı çıkarak, hatalarından dersler çıkararak mücadele etmeye başlar. Ifemelu, Amerikan aksanına ya da İngiliz aksanına öykünen ve Amerikalılar ve İngilizler gibi İngilizce konuşmaya çalışan, onlar gibi davranan, onlar gibi yaşayan Afrikalı göçmen ve öğrenciler gibi aksan edinmeyi uyumun ilk şartı olarak düşünür ve onlar gibi konuşmaya çalışır. Ancak diğerlerinin aksine Ifemelu kısa bir süre sonra Amerikan aksanının kendi duygusal dili olmadığını hissedince bu çabadan vazgeçer. Ifemelu'nun toplumsal cinsiyetin ayrımına daha çok varması 
Amerika'da ırksal ve sınıfsal farklılıkları gözlemlemesi ve yaşaması ile eş zamanlı olur. Özellikle önyargıların ve basmakalıp düşüncelerin, kadınların ve özellikle de siyah kadınların baskılanmasında önemli olduğunu görür. Ancak Ifemelu statüsünü kabul etmek yerine muhalif ve geleneklere uymayı reddeden bir tarz benimser. Zaman zaman bu tarzı toplumun her kesiminde açık ya da gizli olarak bulunan ırkçılık nedeniyle eleştirilse de mücadelesinden vazgeçmez. Aynı şekilde okula uyumda zorluk çekse de bir süre sonra ortama alışır ve başarılı olmaya başlar. İlişkilerinde de tabuların ya da beklentilerin dışında beyaz bir erkekle uzun süren bir ilişkisi olur. Yazmaya başladığı blogunda, özellikle Afro-Amerikalıların ve Afrikalı göçmen ve öğrencilerin yaşadıkları sorunlarından bahseder ve kısa zamanda çok ilgi görür. Blog yazılarının aldığı tepkiler, davet edildiği toplantılar, tanıştı̆̆ kişiler, yaptığı yolculuklar Ifemelu'nun hem maddi olarak hem duygusal ve zihinsel olarak gelişmesine yardım eder. Romanda hem Amerika Birleşik Devletleri'nde hem Birleşik Krallık'ta Ifemelu ve Obinze'nin karşı karşıya kaldıkları sorunlar benzer olmasına rağmen Obinze'nin kaçak olması, sürekli ekonomik sorunlarla boğuşması ve çözüm yollarının işe yaramaması sonucu en sonunda Birleşik Krallık'tan sınır dışı edilirken Ifemelu Amerikan vatandaşlığı alır ama aynı durumda olan insanlardan farklı olarak kendi isteği ile ülkesine döner. Ancak her ne kadar bir 'Americanah' olmaya yani hareketleri, tavırları, konuşması ve yaşam tarzı ile Amerikalılar gibi olmaya dirense de Nijerya' ya döndükten sonra ister istemez kendisinin de değiştiğini, bazı davranışlarının, konuşma tarzının, yeme alışkanlıklarının, zevklerinin az da olsa farklılaşı̆̆ı̆ıı, Lagos'u ve sıcak havayı garipsediğini, Amerika'da alıştı̆̆ı bazı yiyecekleri özlemeye başladığını hisseder. Yani ırkçılık, ayrımcılık, ekonomik sorunlar, yalnızlık, suiistimal, işsizlik ve hayal kırıklıkları gibi sorunları yaşamış olsa da, özentilerinin ve öykünmelerinin sürüklediği bir kişi olup tamamen özünden uzaklaşan bir 'Americanah' olmamak için mücadele edip, kişiliğini ve özelliklerini korusa da sonunda az da olsa değişir. Ancak Ifemelu'nun değişimi yapıcı ve olumlu bir gelişme olarak görünmektedir. 
Chimamanda Ngozi Adichie is an award-winning and much-acclaimed Nigerian author with three published novels, Purple Hibiscus (2003), Half of a Yellow Sun (2006) and Americanah (2013), a short story collection, The Thing around Your Neck (2009), and two books of non-fiction, We Should All Be Feminists (2014) and Dear Ijeawele, or A Feminist Manifesto in Fifteen Suggestions (2017). She is a selfacclaimed feminist and resident in both Lagos, Nigeria and Maryland, the US. Like Chinua Achebe, Wole Soyinka, Flora Nwapa and Buchi Emecheta, the other authors of Nigerian background, her works have been popular in many countries and come to be widely read and studied in literary and academic circles.

In Americanah, which contains many autobiographical elements, the novel's protagonist is a female character, Ifemelu who goes to the United States of America for university education on communications from Nigeria in the early 2000s, enjoying the opportunities offered by the 1965 Immigration Act which ended race and sex discrimination for the prospective immigrants to the USA and paved way for "the creation of a more diverse modern America" (Villazor 2015: 1). The novel starts with Ifemelu reminiscing about her life in a beauty salon in Trenton, New Jersey. In 7 parts and 55 chapters, the novel proceeds with flashforwards and flashbacks, and alternate points of view of Ifemelu and Obinze who travels to the United Kingdom and back. As Levine posited, "she offers us the changing perspectives of her two migrant protagonists who move between countries and climb and fall in personal wealth" (2015: 601). After 13 years in the United States, Ifemelu goes back to Lagos despite the evident success and popularity of her blog, 'Raceteenth of Various Observations About American Blacks (Formerly Known as Negroes) by a Non-American Black', her research fellowship at Princeton University, her American citizenship and her financial gains.

One of the most prominent issues in the novel is Ifemelu's struggle to have a better life with better education and better qualifications. In the novel, Ifemelu's physical and emotional growth comes to the fore with her negotiation of hardships which enforce immigrants and foreign students to have adaptive strategies like emulations, affectations and denial without compromising her identity and attachments. Adichie opined that "identity is something that shifts often depending on where you 
are and what you are doing, ... they are not competing identities" (Steven Santo's interview). In conformation with Adichie's words, Ifemelu's identity was challenged as a result of her experiences in Lagos and Nsukka in Nigeria, in New York, Princeton, Trenton, and many other cities in the USA and back in Lagos again. Therefore, the novel was described as a "coming-of-age story" (McCoy 2017: 281) of Ifemelu as a young Nigerian woman, which was also defined by Cruz-Gutiérrez as "the journey of development of the novel's protagonist, Ifemelu" (2019: 68). Adichie confirmed that this novel is about Ifemelu's self-development and finding herself (Michelle Norris' interview) and about her resistance to becoming an Americanah after her travel to America as a result of her bitter-sweet experiences and the people she encountered. As Duce stated, "Ifemelu is not the prototypical migrant of postcolonial fiction. She leaves Nigeria neither for political reasons nor due to economic scarcity, but, influenced by her boyfriend's veneration of American culture, she moves to the States in pursuit of personal development" (2021:246).

Indeed, among the people in her life, particularly two women were prominent in her growth as an individual. The first one was Aunty Uju who had always been Ifemelu's confidant and advisor during her adolescence and whose presence in America hastened Ifemelu's decision to have a university education there. Aunty Uju's life as a mistress of a Nigerian general, The General, her subservient position in her relationship with him and her financial dependency on the man despite her profession as a medical doctor influenced Ifemelu a lot for her future life. Obinze's mother, Mrs. Maduewesi was the other character who had a great influence on Ifemelu with her outspoken wit, blunt honesty and strong personality. Mrs. Maduewesi was a professor in literatures in English at Nsukka University. She helped Ifemelu to be a strong-willed woman who did not show any obedience and docility in her relationships and she did not comply with the cultural impositions and traditional roles. She was also the person who raised Ifemelu's consciousness about cultural imperialism, and domestication and oppression of women with her criticism of American pronunciation, American words, American books her son, Obinze read with their long conversations during which they frequently shifted to Igbo. She advised Ifemelu about her relationship with her son and warned her that she would have to bear the consequences of their mutually agreed acts because "Nature is unfair to women" (Adichie 2013: 72) and because the women were deemed to carry the burden. So, Ifemelu owed a lot to Obinze's mother and Aunty Uju for helping her grow as an individual as she was inspired by their ca- 
reers, perseverance and determination. She learned from their mistakes and she defied the racial, cultural and social restrictions rather than being apologetic or shying away (Synne Rifbjerg's interview) Besides, Mrs. Maduewesi's reaction to another professor who slapped her face and Ifemelu's father's resignation in order not to call his new female boss as 'mummy' left deep traces on her and she learned not to bow down to physical and verbal violence and mobbing throughout her life.

Apart from the influence of these two women on her, the novel reiterated the inalienable effects of being a foreigner in another country and most characters are depicted to be vulnerable because of their aspirations and affectations in order to make a living abroad. Naturally, as a young woman with a lot of dreams, Ifemelu was prone to her pretensions, too, as she compromised her three years at Nsukka University to obtain "a measure of physical and linguistic security" (Esplin 2018: 74) and to have a better life with a degree from an American university. As Landry (2018) stated, she was "voluntary migrant" who wanted to live like the Americans she watched on TV and she dreamed of a life in the USA with Obinze wishing to live like the people on TV whose "full of bliss, where all problems had sparkling solutions in shampoos and cars and packaged foods" (Adichie 2013: 113). But life in America was difficult for most people like Aunty Uju, a medical doctor, and her son because Aunty Uju had to work at three jobs, retail at a mall, a research assistantship and some time at a Burger King as she was trying to get some qualifications to practice medicine in America. But she still had to scrimp and at the Grocery Store, Uju bought not what she needed but what was on sale. Devoid of the comforts she had enjoyed in Nigeria, Aunty Uju needed a baby sister and so Ifemelu took care of Dike until she got her residency.

Throughout her stay in the USA, Ifemelu's outlook and identity were exposed to the overwhelming pressure of the dominant American culture, the impositions of the host society and the biases of individuals she came across. Ifemelu was luckier than most other students during the first months in the USA thanks to Aunty Uju who provided accommodation for her and she got financial support from her family and Obinze although the money they sent wasn't enough to meet her needs. Besides, her work as a babysitter, her relationships with two men, Curt and Blaine, her graduation and the success and popularity of her blog eased and improved her life in the following years financially, socially and emotionally. However, during the first months when she babysat Dike, Ifemelu had to cope with many troubles she had not foreseen like different lifestyles, habits, cuisine and manners in the new country. Soon 
Ifemeu realized that she was "an ethnicized Other" who inevitably had culture shock that "disrupts cultural scripts and elicits feelings of powerless, confusion, and loss" (Landry 2018: 132) in a foreign land. Ifemelu didn’t like most food except ice cream and thought they were bland. She was surprised to find that nobody used scrubs in the showers. It was another astonishing experience for her to pay for her food and drinks including tips which she regarded as a kind of bribing when she felt invited and therefore not anticipating paying. She envied Americans who enjoyed a wide range of items to consume and to buy unlike people in Nigeria where people had to wrestle with petrol lines, unemployment, military regime, coups, internal conflicts, deprivation, lack of amenities, poor telephone services, shortage of running water, electric cuts, corruption, bribery, inequalities of income and strikes.

As for campus life, she was a little confused by the professors' attitude, assignments and participation grades which sharply contrasted with her experiences at Nsukka University and her participation in the classes was minimum. After the culture shock she had during the initial phase, she reasoned that she needed to change in order to succeed and that without changing and adapting to the new condition she was likely to fail. So, she spent a lot of time in the library reading James Baldwin and books about America to understand the culture and people in the country. As a result of the time spent and information she acquired in the library, she was able to participate, raise objections and voice opinions in the class without hesitation. Apparently, rather than being discouraged and retreating, Ifemelu veered towards defiance and struggle to have a better life.

Indeed, Ifemelu's adaptation was not a smooth process during which she solved every problem easily. Outside the university too, life was extremely difficult for her and she needed to earn money although she was trying to save her money carefully. But her credentials, student visa and resolution did not suffice to have a decent life and she needed a fake ID to pretend to be somebody else in order to find a job to meet her needs. A friend of Aunty Uju's, Ngozi, lent her driver's license and Social Security Card which was a blow to her perceived identity as she felt impotent and powerless. She was uncertain and scared to use somebody else's documents because it was a criminal and immoral act; however, Uju told her that black people looked alike to white people and she did not need to worry. She sadly recognized that she needed to compromise in order to make a living. Pretending she was Ngozi, Ifemelu tried to find work as a health aide, waitress, hostess, bartender and cashier with no success. 
She could not pay the school fee or the room rent. She got so much despaired about financial problems that she allowed a man to abuse her sexually in return for money. So, she fell into depression and stopped corresponding with or calling Obinze, her family and she stopped going to school. After finding employment as a babysitter thanks to Ginika, one of her friends from Nigeria, she could get out of her room and get over her shame and depression. She eventually conceded that life in the USA required pretensions and cheating otherwise despair, depression and downfall were looming.

According to Landry, one of "the potentially negative effects of being an ethnicized Other" is "linguistic bias" (2018: 140) for people like Ifemelu. Because, in addition to the detrimental effects of economic problems and culture shock on her, Ifemelu had language issues unexpectedly. She declared to be proud of her Igbo, Nigerian and African heritage and contended with her language skills and her accent. It had never occurred to her that her linguistic versatility would be questioned but on the first day Ifemelu went to the university, the woman at the front desk spoke to her very slowly and asked whether she spoke English although "she had spoken English all her life" (Adichie 2013: 134). She voiced her desire to adopt the accent which seemed the key to success and

she hungered to understand everything about America, to wear a new, knowing skin right away: to support a team at the Super Bowl, understand what a Twinkie was and what sports 'lockouts' meant, measure in ounces and square feet, order a 'muffin' without thinking that it really was a cake, and say 'I scored a deal' without feeling silly. (Adichie 2013: 135)

In addition to her perceived linguistic failure, she became so anxious that she decided to adopt American accent quickly. She was still confused with some concepts like 'Hispanic' and 'half-caste', the former referring to both a language and culture and the latter was taken as an offensive word in America although in Nigeria it was praise for women like Ginika and Kosi to be defined as half-caste. Americans used 'biracial' instead and Ifemelu was supposed to be offended if somebody called her 'half-caste'. She also noticed that Americans preferred speaking with implications and euphemisms rather than saying something directly like saying 'I'm not sure' instead of 'I don't know'. They did not give direct instructions but preferred sentences beginning with 'You may' to deter any misunderstanding or offense. 'Sorry' is another word confusing her because she used it to express her sympathy and sadness for misfortune but Americans used it as an apology in addition to their overuse of words like 
'excited', 'wonderful' and 'beauty'. She was also perplexed by the grammatically incorrect sentences and expressions that did not mean anything to her like 'You're all set' which meant she has made all preparations for the required act.

Speaking English and adopting an American accent were the aspirations of many Nigerians and Africans in America. It was fashionable to speak English and to speak with the American accent was favorable among the Nigerian and African characters in the novel like Kofi, Doris and Akin-Cole who were proud of possessing the perfect American accent. At the Nigerpolitan Club, there were many people who had adopted foreign accents like Fred whose "spirits attuned across the Atlantic ... too eager to show how much he knew of the Western world ... He was an impresario, well oiled and well- practiced, the sort of man who did a good American accent and a good British accent, who knew what to say to foreigners, how to make foreigners comfortable" (Adichie 2013: 410). Another character was Ginika who started talking exaggerated Nigerian English with Ifemelu to prove she had not changed but shifted to American accent with her friends mechanically. Ginika, too, had problems with some words as 'boning' that meant 'to carry face' in Nigeria but 'to have sex' in American English, Besides, there was the practicality in having the accent otherwise they would have to repeat their words again and again like Aunty Uju because a pharmacist told Uju that her accent was incomprehensible. Not only in America but also in Britain the characters like Obinze and Nigel had some communication barriers because of the different accents they had as in the example of Nigel saying 'male' and Obinze thinking that he said 'mile'. For safety reasons, too, having the accent was imperative because Halima's son was beaten at school by the black boys because of his African accent. On the train to Essex, Obinze bitterly remembered that

Once I was with [Emenike] in London and he was mocking this guy he worked with, a Nigerian guy, for not knowing how to pronounce F-e-a-t-h-e-r-s-t-o-n-e-h-a-ug-h. He pronounced it phonetically like the guy had, which was the wrong way, and he didn't say it the right way. I didn't know how to pronounce it either and he knew I didn't know, and there were these horrible minutes when he pretended we were laughing at the guy. When of course we weren't. He was laughing at me too. (Adichie 2013: 434)

Linguistic affectations had some other adverse consequences on the characters. In addition to the struggle of most characters to speak English fluently, they were also portrayed to be making their children speak English well so that they could avoid the problems concomitant with not having the accent. Therefore, children were fre- 
quently discouraged from speaking their national tongues like Igbo, Yoruba, Pidgin English and Nigerian English. Aunty Uju did not want her son, Dike to learn Igbo not to confuse him with two languages. Dike, a first-grader, had already adopted "a seamless American accent and a hyper-happiness about him" as well as American slang (Adichie 2013: 105) and he called Ifemelu as 'Coz' like his American friends not as 'aunty' in the Nigerian way in a similar manner to Aunty Uju who started to pronounce her name in the American way in an effort to conform. Not only in America but also Britain, people from Africa are portrayed to be in an endeavor to speak English. With his son Nna, his daughter, Nne, Obinze's cousin Nicholas spoke "careful English, as though he thought that the Igbo he shared with their mother would infect them, perhaps make them lose their precious British accents" (Adichie 2013: 239). One of Nne's friends' Russian mother pretended "being more British than the British" and behaved as if she did not have a Russian accent (Adichie 2013: 242).

In contrast to the majority of the characters whose linguistic affectations were mirrored in the novel, Ifemelu was different as regards the accent because long before coming to America, she had felt annoyed with her father's "mannered English" which she translated as "his costume, his shield against insecurity ... his armour" for his disappointments and regrets (Adichie 2013: 48). Aunty Uju's date, a Nigerian accountant, Bartholomew, who came 30 years ago to the USA, was another character who was very eager and careful to have an American accent. Ifemelu felt the same for him as she had felt for her father and she understood "a deprived upbringing that he tried to compensate for with his American affectation, his gonnas and wannas" (Adichie 2013: 115). She also disliked it when Ginika who had been to America for some time with her family and came back "pretending she no longer understood Yoruba, adding a slurred $r$ to every English word she spoke" (Adichie 2013: 65).

Ambitions to make a living in America or Britain intermingled with affectations and this situation usually resulted in the loss of linguistic diversity and youngsters like Dike grew monolingual deprived of his rich linguistic repertoire and cultural heritage. If the immigrants and students from African countries came to the USA "with the flexibility and fluidness of youth" they could adopt the accent and learn new languages and they allowed "the cultural codes [to seep] into [their] skin (Adichie 2013: 110). But the younger generations in the USA were unable to or did not bother "code-switching any more" (Adichie 2013: 342). They did not have a chance to speak Ebonics or they spoke only Ebonics as they were deprived of "the fluidity" of the 
previous generations (Adichie 2013: 342) who were able to speak a few languages and dialects.

Despite the external factors obliging the characters to speak English and to adopt the American accent, obviously American English or British English was not their emotional language. "In order to transmit a wide range of her Igbo characters' emotions" (Murphy 2017: 100), Adichie resorts to the other languages and dialects in her linguistic repertoire in the novel as the novel is replete with Igbo speech elements which are italicized and sometimes followed by English equivalents, sometimes the meanings to be inferred contextually. That "ethnic experiences are here expressed in a heritage language" (Koziel 2015: 109) underlines that the characters' instant and natural choice was either Igbo, Pidgin or Nigerian English with which they felt most comfortable in spite of occasional code-switching. Ifemelu felt that her father forgot about his worries when he spoke Igbo despite his aim to speak English well. Aunty Uju was very keen on her son's learning English but she shifted to Igbo when she was angry with Dike. Another remarkable example of their use of other dialects and languages took place during the conversation about the cost Obinze had to pay to borrow another Nigerian man's NI number. Their conversation began in English, shifted to Nigerian English, then to Igbo and finally to a rural accent in the course of their talk because they had to talk about the details and the language they could express themselves perfectly was their rural accent. Another factor dictating the use of emotional language was friendship and intimacy as it happened between Ifemelu and Kayode at a mall. As soon as they saw each other, their language shifted into Nigerian English, "both lapsing into their Nigerian voices and their Nigerian selves, more heightened, adding 'o' to their sentences" (Adichie 2013: 222). In like manner, Ebonics was a better choice for Blaine and Mr. White, the security guard at the library, rather than American Standard English during their small talks. Obinze saw that most Nigerians spoke Yoruba, Igbo or Pidgin among themselves although they avoided those dialects and languages in their contacts with the members of the host society who frowned upon other dialects and languages.

Another issue which heightens the sense of vulnerability of the characters to external aspects is their propensity to imitate falsified beauty ideals which dictate Caucasian models. Ifemelu's recognition that race and class mattered in America coincided with her growing awareness of gender and these issues were interwoven. She reasoned that particularly the stereotypes and biases about beauty were instrumental in 
the oppression of women and principally in the oppression of black immigrant women. Seeing a magazine covering a white woman in an African country with black kids allowed Ifemelu to protest that "her skinniness is by choice and theirs is not by choice" (Adichie 2013: 162) emphasizing the different circumstances people faced in different parts of the world. On Ifemelu's first encounter with Blaine during a train ride, she happened to be reading a woman's magazine with "images of small-boned, small-breasted white women on the rest of the multi-boned, multi-ethnic world of women to emulate" (Adichie 2013: 178) propagating the white women's bodies as the norm. Curt, a white man, criticized the women's magazine, "Essence", as "racially skewed" (Adichie 2013: 294) for only featuring black women because he was unaware that the contents of most women magazines dictated beauty standards according to white women and featured mainly and extensively white women. Ifemelu and Curt scanned a lot of magazines together and found out that in almost two thousand pages there were only three biracial or racially ambiguous black women in addition to the absence of black women in popular cultural production. Every beauty item was commercialized according to the needs and standards of the white women therefore color of hair products, makeup materials like eyeshadows and lipsticks, underwear and band-aid did not fit black women's skin color or preferences. Thus, Aunty Uju's attempts to conform to the rampant norms of beauty and hairstyle could be related to her desire to be accepted into the mainstream society by imitating white women. When Aunty Uju finally passed the exams, she decided to take her braids out for interviews as she concluded that it was improper (Adichie 2013: 119). Ifemelu did the same and loosened her braids in order to look professional in parallel to "the expectations in America for the immigrant to be as unmarked as possible and to assimilate to American standards" (McMann 2018: 208). But she felt uncomfortable and depressed because changing her looks was an annoying affectation for her, an act which she never repeated.

Nevertheless, Ifemelu's nonconformist attitude and unyielding commitment to self-improvement were hampered by overt and covert forms of racism that permeated every section of the society. She had not been color-conscious and she had not recognized the taboo words like 'nigger', 'half-caste' or 'fat' before coming to America. She observed that particularly the white people who were very uncomfortable and tense with racial categorizations pretended to have overcautious manners, exaggerated attitude and "hyper-aware[ness] of difference, any difference" (Adichie 2013: 293). Adichie posited that "Americans circle around, invent codes" to avoid 
the subject (Synne Rifbjerg's interview). Their presumptions that America was colorblind complicated the race issue even worse and caused "the willful ignorance of supposedly liberal white Americans with "good" intentions but who fail to grasp the significance of systemic racism echoes throughout Americanah ... the implicit biases, microaggressions, and everyday acts of institutionalized white racism that negate the existence of black people" (McCoy 2017: 284). One of her early encounters with this careful and evasive attitude took place in class when they watched 'Roots' and Kunta Kinte's life. When the professor asked about historical representation in the film, Ifemelu protested the bleeping of the word 'nigger' out as she believed that word reflected reality and it caused a lot of pain in history. The professor indirectly mentioned the word as $\mathrm{N}$ and still avoided the word despite the heated debate in the class. Another incident also taught her the American way of avoiding the taboo. In a store, the cashier wanted to learn which assistant helped them to give the due commission but instead of asking simply the racial signifiers of black and white, she asked some other questions which did not help to identify the true person. These two incidents served to support the prevalent conviction that "because this is America, you're supposed to pretend that you don't notice certain things" (Adichie 2013: 127).

Ifemelu defied "this relative silence" of the Americans as she sensed that "race occupies a strange place in the American consciousness. It is omnipresent, but treated as if it is invisible or as if it simply does not exist" (McMann 2018: 209). But racism did exist in America and Ifemelu personally became the target of some racist attitudes. Once in a beauty salon they refused to wax her eyebrows and they agreed to do it only after Curt interfered. She said:

I came from a country where race was not an issue; I did not think of myself as black and I only became black when I came to America. When you are black in America and you fall in love with a white person, race doesn't matter when you're alone together because it's just you and your love. But the minute you step outside, race matters. But we don't talk about it. We don't even tell our white partners the small things that piss us off and the things we wish they understood betters, because we're worried they will say we're overreacting, or we're being too sensitive ... But we don't say any of this stuff. We let it pile up inside out heads ... we say that race doesn't matter that's what we're supposed to say, to keep our nice liberal friends comfortable. (Adichie 2013: 290-291)

Lyle who reads Americanah as "an epitome of Afropolitan fiction" claims that 
“... Americanah moreover underlines that sexuality is political and that it is intimately intertwined with questions of race, nationality, and culture" (2018: 113,120). During her relationship with Curt, Ifemelu became self-conscious because of the different colors of their skins. Everywhere they went together, in the eyes of the white girls and as they walked hands clasped on strangers' eyes she read "Why, her?" because she was beautiful but "she was not light-skinned, she was not biracial" (Adichie 2013: 293). In restaurants, too, sometimes she felt the coldness of the waiters who disapproved of their relationship. Against all odds, she kept on dating Curt and she deserted him with her own decision when she caught him flirting with another woman.

Two other incidents in the novel serve to shed light on the racial biases of the Americans they were so carefully trying to hide as two black men were easily stigmatized and made scapegoats just because of the color of their skin. Although Americans were disposed to avert the issue and behaved as if there had not been any racial issues, their half-hearted neutralism gave way to deep-seated biases which resurfaced quickly. The librarian thought Mr. White, the guard at the library, was drug-trafficking and called the police for his suspicions for a trivial reason and Dike was accused of hacking the school's computer network although he had nothing to do with it because of the habit of "You have to blame the black kid first" (Adichie 2013: 349). It was also remarkable that the school authorities offered to place Dike in the special class during the period he was pressured by his emotional trauma and stigmatized him as mentally retarded. There are other characters in the novel who were subjected to racism in different ways like Shan and Blaine whose mother was not allowed to rise at work because she was black while white people denied racism and tried to complicate the issue. White people were also ready to make accusations against black people as it happened to Aunty Uju when a man told Aunty Uju to go back to the country she came from just because she refused to give him the medicine he wanted.

Particularly the race issue underlay the discontentment and disillusionment of the characters in Adichie's novel and provided the main impetus for Ifemelu's blog in which she started to share her opinions and observations she was unable to talk about. Ifemelu "learns how to traverse the new and foreign racial terrain of the United States, regularly chronicling her life and hard-won lessons through blogging" (Landry 2018: 128). As the name suggests, her posts in her blog were mainly about the race issues in America and the candidacy of Obama and Hillary Clinton for the presidency of the United States in 2007 and 2008. Blogging was significant in her life because it 
allowed her "to break with the stereotypes, simplistic definitions, and traditional roles created and imposed by Western culture, as well as enabling [her] to express [her] own experiences, perspectives on history, stories and voices that would otherwise remain unheard" (Duce 2021: 244). She criticized the discrimination against people of different races and the inequalities and biases in the country. She posited that there were four tribalisms in the States: class, ideology, region and race as she observed that Hispanics, blacks, Asians and Jews were treated badly in the country with blacks "at the bottom of America's race ladder" (Adichie 2013: 220). She wrote that although there were some improvements in the lives of the black people since the 1960s, it was still a reality that black people were denied bank loans/mortgages; white juries gave worse sentences to black criminals; white policemen stopped black men while driving; a black man was more likely to be sent to prison if caught with drugs unlike a white man who was likely to be sent to treatment.

The picture Ifemelu drew in her blog about the racial problems was rather gloomy because she claimed that there were more white people on TV and few nonwhites on the school books; admittance to social clubs was difficult for non-whites; non-whites were harassed or followed in the shops; black success was considered exceptional and managerial positions were held by white people. She expressed her concern about the disadvantages for black people for employment and their presence in a nice neighborhood. If black people raised their voice about these inequalities and discriminatory acts and attitudes, they were blamed for 'playing the race card' and doing 'reverse racism'. In other words, white people turned a blind eye to the prevalent racism and pretended that black people were abusing the situation instead of accepting the problem. Ifemelu could find only find relief after she returned from America as she told Zemaye that she discovered 'race' in the US and told Blaine on the phone that race did not work in Nigeria because only after she arrived back in Lagos she felt she "stopped being black" (Adichie 2013: 476).

On the other shore of the Atlantic, Obinze suffered from similar problems during the three years he spent in Britain. Despite his past aspirations for studying in America with "a longing nurtured and nursed over many years" (Adichie 2013: 232), he was not qualified for a visa. He was able to go to the UK as an assistant to his mother who was invited there for a conference and he did not return with his mother. So, his credentials provided life in the UK only as an illegal immigrant. He felt that the British people were fearful of being swamped by the steeply increasing number 
of immigrants, refugees and asylum seekers which was "infecting everybody with the panic of impending doom ... the influx into Britain of black and brown people from countries created by Britain” (Adichie 2013: 258). Therefore, British people sometimes treated people of different colors with coldness, suspicion and hostility and illegal immigrants were quickly deported from the country. Throughout his three years in the UK, in addition to loneliness and financial problems which frustrated his efforts to survive, he was distressed with his status as an illegal immigrant as a nobody living "in London indeed but invisibly, his existence like an erased pencil sketch; each time he saw a policeman, or anyone in a uniform, anyone with the faintest scent of authority, he would fight the urge to run" (Adichie 2013: 257). It was impossible for him to survive and to do the meanest jobs as an illegal immigrant so he was compelled to use another person's identity and "live as a shadow" (Synne Rifbjerg's interview) in a similar manner to Ifemelu. The only way to have legal status in Britain was through marriage with a British or European Union country citizen which changed their lives immensely. Obinze sensed Emenike looked so self-contented because "He was married to a British woman, lived in a British home, worked at a British job, travelled on a British passport" and he envied Emenike (Adichie 2013: 267). The only way he could continue his life in the UK was through sham marriage for which he paid a large sum of money to some Angolans. However, just before the marriage, he was arrested and deported from the UK. After he became rich and had his visas for the USA and the UK, he never forgot his humiliating deportation from Britain and still refused to fly the British Airways on the pretext that they treated him badly during the flights.

After some time in America, Ifemelu was so much overwhelmed by her new society, new worries and new challenges, the troubles she had been accustomed to in Nigeria started to look "foreign to her, and home a distant place. She could no longer remember what it felt like to spend an evening in candlelight" (Adichie 2013: 159). She grew uncertain of her affinities and her attachments as "home was a blurred place between here and there" (Adichie 2013: 117). Concurrent with this uncertainty was her change due to the unassailable influence of the American accent as she realized that she involuntarily started using some of the most frequently used words like 'excited". In her attempt to learn and adopt the accent "She had perfected, from careful watching of friends and newscasters, the blurring of the $t$, the creamy roll of the $r$, the sentences starting with 'So', and the sliding response of 'Oh, really"' (Adichie 2013: 173). She proved her mastery of American English when a telemarketer praised her 
English to be sounding totally American. But this compliment over her versatility of the American accent did not please her; on the contrary, she said 'thank you' but later reconsidered and wondered why it was "a compliment, an achievement to sound American" (Adichie 2013: 175). It was a crucial moment in her life when Ifemelu decided to reclaim her heritage, her roots and her language because she felt that "the accent creaked with consciousness, it was an act of will. It took an effort, the twisting of lip, the curling of tongue. If she were in a panic, or terrified, or jerked awake during a fire, she would not remember how to produce those American sounds. And so she resolved to stop ... faking an American accent" (Adichie 2013: 173, 175). From then on, she started to pronounce in her Nigerian manner which was "truly her; this was the voice with which she would speak if she were woken up from a deep sleep during an earthquake" and she felt that "She returned to her own voice" (Adichie 2013: 175, 180).

Her decision to reject "her own habits of phoniness" (Levine 2015: 593) was the beginning of a new phase in her life because from then on she made her selections including the dialect she was to use in order not to be subdued like Aunty Uju and not to transform into an 'Americanah' like Ginika and members of the Nigerpolitan Club. Adichie defined an Americanah as a person who went to America, had affectations and pretended as if they did not understand Nigerian English (Librairie Mollat's interview). This decision was the beginning of the process Obinze defined as 'opening' of her eyes (Adichie 2013: 240) during which she began "taking pride in [her] heritage" and striving to retain "prominent cultural attributes" (Amonyeze 2017: 3) unlike some other immigrants and students who were assimilated into the American society.

Her dissimilarity with the others could also be traced to her attempts to quench "a hunger, a restlessness. An incomplete knowledge of herself" (Adichie 2013: 289) in a rather incongruent manner. In order to fulfill her aims and to improve herself, she made drastic strides of self-fulfillment rather than conforming to the cultural codes and standards in America. Even when she found a job as a babysitter for a white couple, she did not accept the offer to live in the same building without any rent and she criticized the way they were raising their kids. She thought it was wrong "to overwhelm a child of four with choices, to lay on the burden of making a decision, was to deprive her of the bliss of childhood" (Adichie 2013: 167). She did not want to raise children in America because the American children spoke with fewer words and with gestures. She did not "want a child who feeds on praise and expects a star for 
effort and talks back to adults in the name of self-expression" (Adichie 2013: 456). Upon seeing Americans cheating in driving license tests in Brooklyn, she grasped that Americans, too, were stricken with their own failures, inconsistencies and insufficiencies. She also criticized Americans' tendency to use medicine for every problem they had. She disapproved of the shallowness and pretensions of some Americans about African people who saw Africa as a continent where poverty and wars prevailed and there their charity was needed and it was a privilege for the Africans to come to the States.

She was keen on preserving her personality and she didn't want to change for what she regarded as the worse. Although it had been a year since the beginning of her relationship with Blaine she refused to blend with his group of friends. She did not like the world of academics, either. Because she believed that the academics were living with their different pretensions and languages on a parallel universe. Her blog provided her with an outlet in which she could write frankly and she seriously opined about the issues she regarded as important; however, even her blog, emails and social media accounts were aiming to produce "the air of unreality, the careful manipulation of images" and "to create a parallel life ... placing in the background the things of which they were proud" (Adichie 2013: 369) as she was articulating the issues she was unable to talk about with anybody else. She was invited to deliver speeches by different institutions for fees covering hotel and travel expenses. She attended diversity workshops and multicultural talks but she realized that the audience wanted to hear her say progress was made in race relations and they were expecting her to voice the opinions that were resonating with their beliefs.

Unlike Obinze whose adventure in Britain ended in dismay as he was 'leveled' in London (Adichie 2013: 244), Ifemelu refused to conform to the affectations and roles she was to play. Dating a white man or African-American was going out of the boundaries and although she needed to loosen her braids previously, her decision to braid her hair could be taken as "a stubborn refrain from Western aesthetic customs" (Amonyeze 2017: 5). Darroch underlined Ifemelu's rejection of the imposed beauty standards and "gendered and racialized bodies that are perpetually forced to re-enact histories of colonialism, slavery, Christian imperialism and civility via neo-colonial systems of "body shaming" (such as natural black hair as a symbol of barbarity)" (2020: 136) as a manifestation of her strength. Despite all the hardships, setbacks, pretensions, disappointments and vulnerabilities she underwent particularly during 
the first year, she was able to regain her self-esteem and "She's gone, she's learned and she's conquered" (Adichie 2013: 433). Ifemelu graduated from the university, she had a fellowship at a university, her blog proved a success, she earned sufficient money to make a decent living in America, to sponsor the travel of her parents to the USA, to afford a car and a flat and she went through the naturalization process and obtained American citizenship. However, after 13 years abroad, at the university campus, she expressed her dissatisfaction and discontentment "in this place of affluent ease, she could pretend to be someone else, someone specially admitted into a hallowed American club, someone adorned with certainty" (Adichie 2013: 3). She did not choose to live in America and willingly she went back to Nigeria simply because she was utterly homesick. Her decision was unusual for a Nigerian woman who succeeded in America and her friends and even the employees at the hair salon expressed their astonishment at her decision to go back apart from their incomprehension of her insistence on Nigerian English.

Although Ifemelu contended that she did not lose her identity, her cultural roots and heritage as she resolutely resisted transforming into being an Americanah like Ginika, she was upset when she came to Lagos after 13 years with the hot weather, traffic jam, heaps of rubbish with "the dizzying sensation of falling, falling into the new person she had become, falling into the strange familiar" (Adichie 2013: 385). She saw people changed, the city changed and the country changed. Reading her bafflement, her friend, Ranyinudo teased her for being Americanah and being estranged. Adichie, too, said Ifemelu became "she is the kind of American but not quite" (Synne Rifbjerg 's interview). Ifemelu got angry with her friend who texted as she was driving, which was a common behavior of drivers in Nigeria. She thought the houses she had liked once were kitsch and Lagos seemed ugly with potholes on the roads, unplanned houses and confusion. She was unable to breathe because of humidity and it gave another chance to her friend to tease her as Americanah. Although she was not anticipating such a change she found herself missing American food which previously had not appealed to her palate in a similar manner to the members of the Nigerpolitan club who frequently talked about "the things they missed about America like low-fat soya milk, NPR, fast Internet, good customer service, a decent vegetarian place" (Adichie 2013: 408). As Landry emphasized, "in the beginning, Ifemelu scoffs at the notion of being completely changed by her time in America, but when she decides to return to Nigeria, she realizes that she is an "Americanah," an amalgamation of both cultures" 
(2018: 144). However, she adapted to her land quickly because she was eager to make up for what she had missed. Despite the years abroad she felt she was home and "Having this job, now that she was home, made her feel anchored" (Adichie, 2013: 411). Nevertheless, the possession of her American passport made her happier and safer as it offered choices to her.

To conclude, Ifemelu's financial, emotional and mental growth which was initiated by two women, Aunty Uju and Mrs. Maduewesi, in her childhood and adolescence transformed her into a courageous young woman who refused to conform to the norms, roles, behavior and manners of the majority in Nigeria and in her prolonged stay in the USA. Although she had to grapple with unemployment, loneliness, sexual abuse, rejections, disappointments and insidious and covert forms of racism in the early months of her stay in the USA, she was not debilitated, overwhelmed or paralyzed. On the contrary, she refused to accept or act according to the racial, social and traditional norms and rejected the gender stereotypes, racial biases, white beauty standards and linguistic codes. In other words, Ifemelu did not act in compliance with the unwritten but deep-seated codes of success in a foreign land and she did not bow to the economic, linguistic, cultural and moral impositions. Although her struggle for self-improvement was jeopardized by racist acts, she was able to negotiate her affectations, aspirations and emulations. She also overthrew the visible and invisible hurdles of class and gender dictated by American and Nigerian cultures, traditions and societies. Ifemelu did not deny her cultural legacy, her home country, her people or her language and she always felt proud of her heritage. She was not the only one who suffered and succeeded in a foreign land but unlike the other characters she did not veer towards assimilation and blind imitation with her nonconformism, strong will and passion. Although she negotiated affectations and fallacies posed by the dominant American culture she could not help changing personally to some extent as a result of her long residence in the USA. Despite drastic strides of self-fulfillment rather than conforming to the cultural codes and standards in America, she could not help changing due to the unassailable influence of the dominant culture and she ended up becoming an americanah with a small a who changed slightly, positively and constructively in her behavior and outlook. 


\section{References}

Adichie, C. N. (2013). Americanah. London.

Adichie, C. N. (2014, May 20). Synne Rifbjerg's interview with Chimamanda Ngozi Adichie [Video]. Youtube. https://www.youtube.com/watch?v=b8r-dP9NqX8\&lc= UgjoqiQZCsPD1XgCoAEC

Adichie, C. N. (2014, June 05,). Steven Santo's interview with Chimamanda Ngozi Adichie [Video]. Youtube. https://www.youtube.com/watch?v=EsWfm0_xgkc

Adichie, C. N. (2014, November 04). Michelle Norris' interview with Chimamanda Ngozi Adichie [Video]. Youtube. https://www.youtube.com/watch?v=2ijEqposkyk\&lc= UggAhaDH7hZd23gCoAEC.83NUNgvaCUY8PySmrJYWBJ

Adichie, C. N. (February 10, 2015). Librairie Mollat's interview with Chimamanda Ngozi Adichie [Video]. Youtube. https://www.youtube.com/watch?v=Rh5qNYU-_jI

Amonyeze, C. (2017). Writing a new reputation: Liminality and bicultural identity in Chimamanda Adichie's Americanah. Journal of Black Studies, April-June, 1-9. https://doi. org/10.1177/2158244017712773

Cruz-Gutiérrez, C. (2019). Hair politics in the blogosphere: Safe spaces and the politics of selfrepresentation in Chimamanda Adichie's Americanah. Journal of Postcolonial Writing, 55(1), 66-79. DOI: 10.1080/17449855.2018.1462243

Darroch, F. (2020). Journeys of becoming: Hair, the blogosphere and theopoetics in Chimamanda Ngozi Adichie's Americanah. Cope, 10, 135-150. http://dx.doi.org/10.18778/20832931.10 .08

Duce, V. (2021). Social media and female empowerment in Chimamanda Ngozi Adichie's Americanah.The EuropeanLegacy, 26(3-4),243-256.DOI: 10.1080/10848770.2021.1891667

Esplin, M. (2018). The right not to translate: The linguistic stakes of immigration in Chimamanda Ngozi Adichie's Americanah. Research in African Literatures, 49(2), 73-86. DOI: 10.2979/reseafrilite.49.2.05

Kozieł, P. (2015). Narrative strategy in Chimamanda Ngozi Adichie's novel Americanah: The manifestation of migrant identity. Studies of the Department of African Languages and Cultures, 49, 96-113.

Landry, A. (2018). Black is black is black?: African immigrant acculturation in Chimamanda Ngozi Adichie's Americanah and Yaa Gyasi's Homegoing. MELUS, 43(4) 127-147. DOI: 10.1093/melus/mly044

Levine, C. (2015). “The strange familiar": Structure, infrastructure, and Adichie's Americanah. MFS Modern Fiction Studies, 61(4) 587-605. DOI: 10.1353/mfs.2015.0051 
Lyle, C. (2018). Afropolitanism for black women: Sexual identity and coming to voice in Chimamanda Ngozi Adichie's Americanah. Aspeers Emerging Voices in American Studies, 11, 101-123.

McCoy, S. A. (2017). The "Outsider Within": Counter-narratives of the "New" African diaspora in Chimamanda Ngozi Adichie's Americanah. Journal of the African Literature Association, 11(3) 279-294. DOI: 10.1080/21674736.2018.1424389

McMann, M. (2018). 'You're black': Transnational perceptions of race in Chimamanda Ngozi Adichie's Americanah and Andrea Levy's Small Island. Critique: Studies in Contemporary Fiction, 59(2), 200-212. DOI: 10.1080/00111619.2017.1369387

Murphy, E. R. (2017). New transatlantic African writing: Translation, transculturation and diasporic images in Chimamanda Ngozi Adichie's the thing around your neck and Americanah. Prague Journal of English Studies. 6(1), 93-104. DOI: 10.1515/pjes-2017-0006

Villazor, R. C. (2015, October 10). The immigration act of 1965 and the creation of a modern, diverse America. Retrieved February 10, 2021 from https://www.huffpost.com/entry/ the-immigration-act-of-19_b_8394570Web. 10 February 2021 